\title{
The Effects of an Experimentally Induced Unilateral Varicose Ovarian Vein on the Activities of Anti-Oxidant Enzymes in an Adult Rat Ovary
}

\author{
Efectos de la Inducción Experimental Unilateral de una Vena Ovárica Varicosa Sobre las Activida- \\ des de las Enzimas Anti-Oxidantes en Ovarios de Ratas Adultas
}

Babatunde Adebayo Kehinde*; Niloufar Abbasi**; Farid Abolhassani***;
Tayebeh Rastegar ${ }^{* * * *}$; Erfan Daneshi****; Mehdi Abbasi*** $^{* * *}$

KEHINDE, B. A.; ABBASI, N.; ABOLHASSANI, F.; RASTEGAR, T.; DANESHI, E. \& ABBASI, M. The effects of an experimentally induced unilateral varicose ovarian vein on the activities of anti-oxidant enzymes in an adult rat ovary. Int. J. Morphol., 34(4):1436$1441,2016$.

SUMMARY: In this study, we aim to examine effects of an experimentally induced unilateral varicose ovarian vein on the activities of anti-oxidant enzymes in an adult rat ovary. In this experimental study, a total of 30 adult female Wistar albino rats were divided into three groups. 10 rats in group 1 as the varicocele group, 10 rats in group 2 as the control group and 10 rats in group 3 as the sham group, that underwent a sham operation and. Anti-oxidant assays were assessed via specific assay kits. Statistical analysis was performed using the one way ANOVA and Tukey's tests were used for post hoc multiple comparisons, $\mathrm{P}<0.05$ was considered statistically significant. The effects of the unilateral varicosity was more evident on the left side when compared to the right side as all activities of the anti-oxidant assayed were significantly reduced, $\mathrm{P} \leq 0.05$ when compared to the right side. Also, in this present study, the effect of the unilateral varicose vein was bilateral as there were no significant differences recorded between the two sides. Finally the result of this study shows that varicocele may lead to female infertility through various factors that includes reduction in the activities of anti-oxidant enzymes.

KEY WORDS: Varicocele; Anti-oxidant; Unilateral.

\section{INTRODUCTION}

Reactive oxidative stress. Reactive oxygen and nitrogen species (ROS and RNS, respectively) include superoxide anion radicals, hydroxyl radicals, hydrogen peroxide $\left(\mathrm{H}_{2} \mathrm{O}_{2}\right)$, peroxynitrite and other peroxides, nitric oxide, and others (Fig. 1). They are very transient species due to their high chemical reactivity that leads to lipid peroxidation and oxidation of some enzymes, and a massive protein oxidation and degradation (Matés et al., 1999). The role of oxygen-derived species in causing cell injury or death is increasingly recognized: superoxide and hydroxil radicals are involved in a large number of degenerative changes, often associated with an increase in peroxidative processes and linked to low antioxidant concentration (Tamagno et al., 1998).

ROS are a double-edged sword - they serve as key signal molecules in physiological processes but also have a role in pathological processes involving the female reproductive tract. They are formed through leakage of electrons from the inner mitochondrial membrane during oxidative phosphorylation and ATP generation.

Oxidative and nitrosative damage occur when ROS and RNS react with cellular lipids, proteins, and nucleic acids (Roede et al., 2010). The relationship between intracellular levels of ROS relative to endogenous antioxidants has a significant impact on this measure. Oxidative stress occurs when increased ROS levels disrupt cellular redox circuits, resulting in disturbances of redox-regulated cellular processes and/or oxidatively damage cellular macromolecules (Jones, 2008).

Moreover, oxidative events may play an important role in the mechanism of action of ether lipids, and oxidizability may contribute to cellular drug sensitivity

* Tehran University of Medical Science, International Campus, Tehran, Iran.

** Faculty of Medicine, Tehran Medical Branch, Islamic Azad University, Tehran, Iran.

*** Department of Anatomy, School of Medicine, Tehran University of Medical Sciences, Tehran, Iran.

**** Department of Anatomy, School of Medicine, Kurdistan University of Medical Science, Sanandaj, Kurdistan, Iran. 
(Wagner et al., 1998). On the other hand, hydrogen peroxide has been implicated recently as an intracellular messenger that affects cellular processes including protein phosphorylation, transcription and apoptosis (Choi et al., 1998).

Antioxidants. Under normal conditions, scavenging molecules known as antioxidants convert ROS to $\mathrm{H}_{2} \mathrm{O}$ to prevent overproduction of ROS. There are two types of antioxidants in the human body: enzymatic antioxidants and non-enzymatic antioxidants (Pierce et al., 2004).

Enzymatic antioxidants. Enzymatic antioxidants are also known as natural antioxidants, they neutralize excessive ROS and prevent it from damaging the cellular structure. Enzymatic antioxidants are composed of superoxide dismutase, catalase, glutathione peroxidase and glutathione reductase, which also causes reduction of hydrogen peroxide to water and alcohol.

Non-enzymatic antioxidants. Non-enzymatic antioxidants are also known as synthetic antioxidants or dietary supplements. The body's complex antioxidant system is influenced by dietary intake of antioxidant vitamins and minerals such as vitamin $\mathrm{C}$, vitamin $\mathrm{E}$, selenium, zinc, taurine, hypotaurine, glutathione, beta carotene, and carotene (Agarwal et al., 2003). Vitamin C is a chain breaking antioxidant that stops the propagation of the peroxidative process. Vitamin $\mathrm{C}$ also helps recycle oxidized vitamin $\mathrm{E}$ and glutathione (Chan et al., 1993). Glutathione is present in the oocyte and tubal fluid and has a role in improving the development of the zygote beyond the 2-cell block to the morula or the blastocyst stage (de Matos et al., 2000).

Biomarkers for oxidative stress. The presence of ROS and antioxidants in the female reproductive tract has been demonstrated by various methodologies in animal and human studies. A number of OS biomarkers have been investigated including superoxide dismutase, glutathione peroxidase, conjugated dienes, lipid peroxides, thiobarbituric acid reactive substances, glutaredoxin, oxidative DNA adducts, follicular fluid, NO and TAC (Jozwik et al., 1999).

Antioxidant defense mechanisms. Multiple enzyme systems and soluble factors maintain the redox state of cells. Some of these are shown in Figure 1. The antioxidant defense mechanisms in cells are complex and appear to be compartmentalized, such that nuclear, cytoplasmic and mitochondrial levels of antioxidants behave independently (Go \& Jones, 2008). Glutathione (GSH), a cysteinecontaining tripeptide, is a key antioxidant present in millimolar concentrations in cells. It can scavenge free radicals through either direct chemical reactions or reduction of peroxides as a cofactor for GSH peroxidases, cycling between its reduced form (GSH) and an oxidized, dimerized form (GSSG) (Anderson \& Luo, 1998). The activity of GSH reductase, which requires NADPH as an energy source, ensures that most GSH is present in cells in the reduced form.

Enzymes like directly detoxify ROS, Superoxide dismutases (SOD) react with superoxide anion radicals to form oxygen and $\mathrm{H}_{2} \mathrm{O}_{2}$. The three main SOD enzymes are copperzinc SOD (CuZnSOD, SOD1, in cytoplasm), manganese SOD (MnSOD, $\mathrm{SOD}_{2}$, in mitochondria), and an extracellular form (ECSOD, SOD3). Catalase, various peroxidases and peroxiredoxins (PRDXs), including GSH peroxidases (GPXs) and some GSTs, can convert peroxides to water.

Together, these interacting defense mechanisms permit cells to live in an oxidative environment, perform necessary biochemical processes, and even use these ROS/ RNS as signaling molecules (Jones). For example, in the ovary there is a transient rise in ROS levels and decline in antioxidant expression after the preovulatory gonadotropin surge, and the rise in ROS is a necessary signal for ovulation (Laloraya et al., 1988).

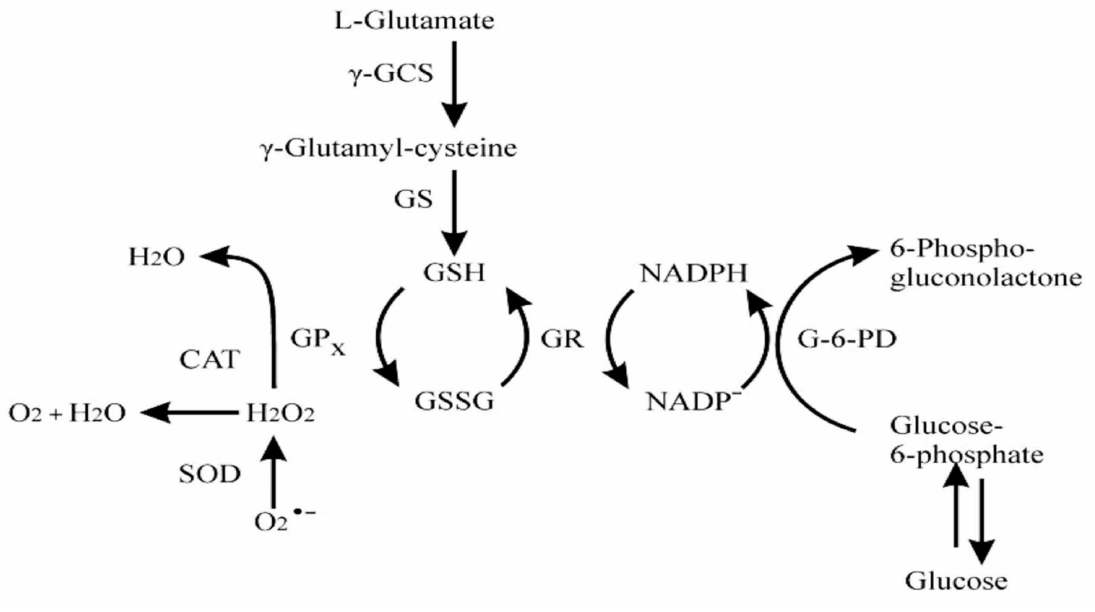

Fig. 1. Key antioxidant enzymes and the reactions they catalyze are shown. CAT, catalase; GPX, glutathioneperoxidase; GSR, glutathione reductase; GST, glutathione-S-transferase; SOD, superoxide dismutase. GPXs and GSTs require glutathione (GSH) as a cofactor, and GSH can also scavenge free radicals through direct chemical reactions. GSR reduces the oxidized form of GSH (GSSG, glutathione disulfide). 


\section{MATERIAL AND METHOD}

Animals. Wistar Albino rats were housed at the Animal Research Center and the study was approved by the Animal Care and Ethics Committee of Tehran University of Medical Sciences. Animals were caged under controlled lighting (12 $\mathrm{h}$ light, $12 \mathrm{~h}$ dark) and temperature $\left(24^{\circ} \mathrm{C}\right)$. Food and water were provided ad libitum.

Rats were divided into three groups. The first group was varicocele $(n=10)$, second group was sham-operated $(n=10)$ and third group $(n=10)$. Left sided varicoceles were produced surgically as described below in the first group.

Surgical procedure. After induction of anesthesia with ketamine $(100 \mathrm{mg} / \mathrm{kg}$ ) and xylazine $(1 \mathrm{mg} / \mathrm{kg})$ intraperitoneally, rats were placed in supine position and a vertical midline abdominal incision of about $3-4 \mathrm{~cm}$ was made. Left renal vein was dissected carefully medial to the insertion of the ovarian vein, and a 4.0 silk suture was placed around the renal vein over a $0.85 \mathrm{~mm}$ metal rod and tied. When the rod was removed, approximately $50 \%$ reduction in the diameter of renal vein was observed to confirm the effectiveness of the surgical procedure. (Fig. 2).Shamoperated rats were subjected to the same vertical midline incision. Left renal vein was identified and dissected similarly. The rod and suture was also placed but not tied. Abdomen was closed without further intervention. All of the rats from three groups were sacrificed after bilateral orchiectomy at the end of 8 weeks. Ovaries were placed in liquid nitrogen and transported to the laboratory. ROS measurements were made immediately.

Homogenization and anti-oxidant assays. Homogenization was carried out with a Teflon end homogenizator (Elvenjem
Potter, Du Pont Instruments, Newton, Conn.) and the homogenates were centrifuged at $1.500 \mathrm{rpm}$ for $10 \mathrm{~min}$ at $4^{\circ} \mathrm{C}$. The plasma was divided and stored at $20^{\circ} \mathrm{C}$ for a few days before the analyses were performed.

The superoxide dismutase (SOD) level was measured spectrophotometrically at $560 \mathrm{~nm}$ as described previously (Durak et al., 1993). GSH-Px activity is measured by following the decrease in absorbance of the reaction mixture at $340 \mathrm{~nm}$, as NADPH is converted to NADP (Paglia \& Valentine, 1967). The decomposition of hydrogen peroxide, which is a measure of catalase activity, can be followed by measuring the decrease in absorbance at $240 \mathrm{~nm}$. The decrease in absorbance was recorded every $15 \mathrm{~s}$, and, for measurement, absorbance differences with 1 min intervals were calculated (Bergmeyer, 1974). CAT activity in tissue homogenates was measured spectrophotometrically at $240 \mathrm{~nm}$ by calculating the rate of degradation of $\mathrm{H}_{2} \mathrm{O}_{2}$ as the substrate of the enzyme using the method of Aebi (Aebi et al., 1984).

Gene expiration by Real Time-PCR. RNA Extraction: Total RNA was extracted from small ovarian tissue with use of an RNeasy kit (74104, QIAGEN, Germany).

cDNA synthesis: Samples were reverse transcribed with use of a first-strand cDNA synthesis kit (330421, QIAGEN, Germany).

PCR with Taq polymerase on the cDNA samples was performed on a sequence detector. Equal amounts of cDNA were used in duplicate and amplified with the PCR mix. Additional reactions were performed on known dilutions of rat cDNA as a PCR template to construct a standard curve relating threshold cycle to template copy number. Amplification efficiencies were validated and normalized against the housekeeping gene.

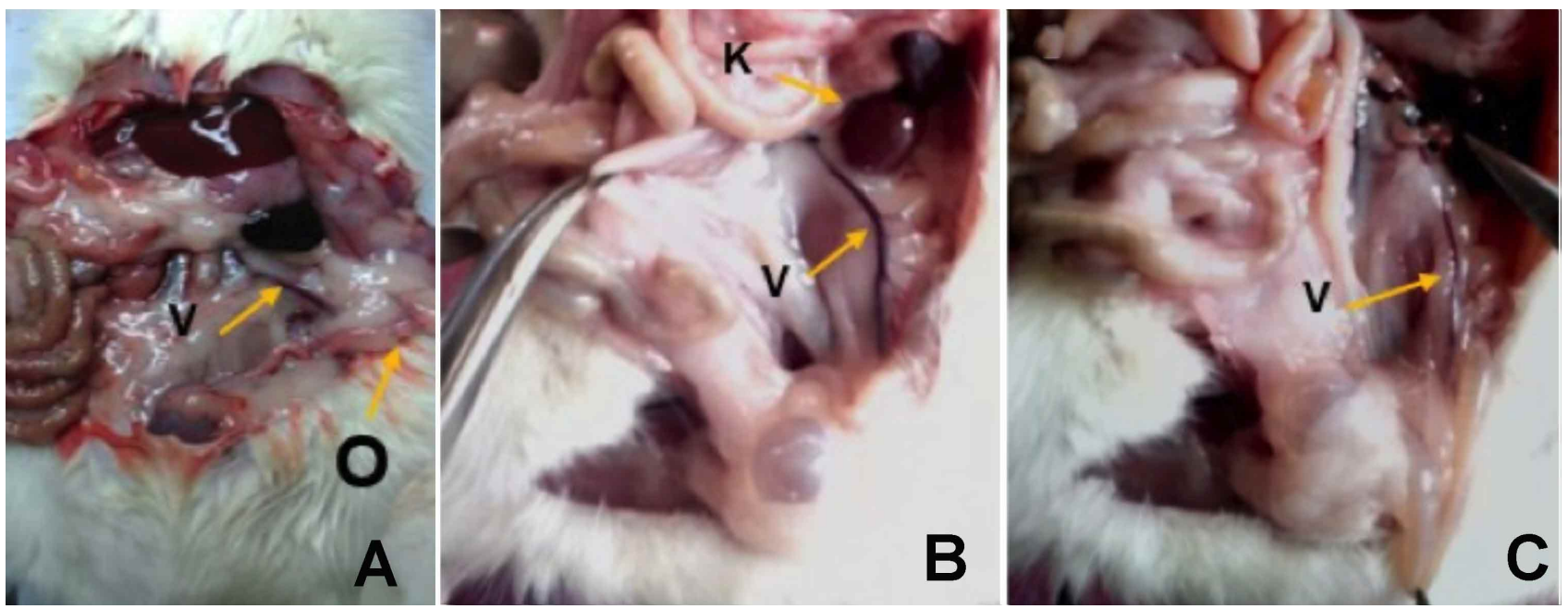

Fig 2. A, B: Distended ovarian vein in varicocele. C: Normal Ovarian Vein (V= Ovarian Vein, O= Ovary, K: Kidney). 


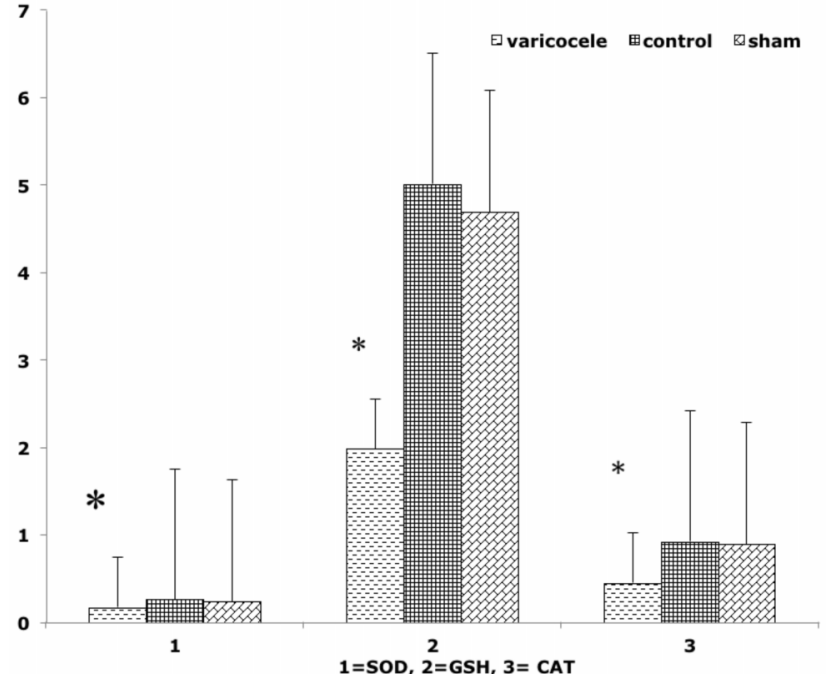

Fig. 3: Shows the graphical representation of biochemical analysis of anti-oxidants enzymatic activities in the three groups on the left ovaries (L). Values are expressed as mean \pm SD. * means statistically significant difference between the groups $(\mathrm{p} \leq 0.05)$. Statistically significant difference was found among the groups for SOD 1, GSH and CAT activities in the varicocele group on the left side $(\mathrm{N}=5$ in each group).

Statistical Analysis. All data were analyzed by SPSS software (Version 22.0, SPSS Inc., Chicago, IL, USA). Statistical analysis was performed using the one way ANOVA and Tukey's tests were used for post hoc multiple comparisons, $\mathrm{P}<0.05$ was considered statistically significant.

\section{RESULTS}

Superoxide dismutase enzymatic activities in ovarian tissues. There were no significantly differences in the SOD enzymatic activities in the right ovaries of all of the three groups (p>0.05) (Fig. 4). The mean values were $0.22 \pm 0.01$, $0.28 \pm 0.01$, and $0.25 \pm 0.006 \mathrm{SOD}$ of $\mathrm{u} / \mathrm{mg}$ tissue in varicocele, control and sham groups, respectively (Fig. 5).

The mean values in the left ovaries were $0.16 \pm 0.01$, $0.25 \pm 0.005$, and $0.26 \pm 0.02 \mathrm{SOD}$ of $\mathrm{u} / \mathrm{mg}$ ovarian tissue in varicocele, control and sham groups respectively (Fig. 5). There was no statistically significant difference among the mean values of all the groups between the left and right side $(p>0.05)$ (Fig.4).

Glutathione peroxidase enzymatic activities. There were no significantly differences recorded in the GSH enzymatic activities in right ovaries of all of the three groups (p>0.05). The mean values were $4.56 \pm 0.22,5.01 \pm 0.08$, and

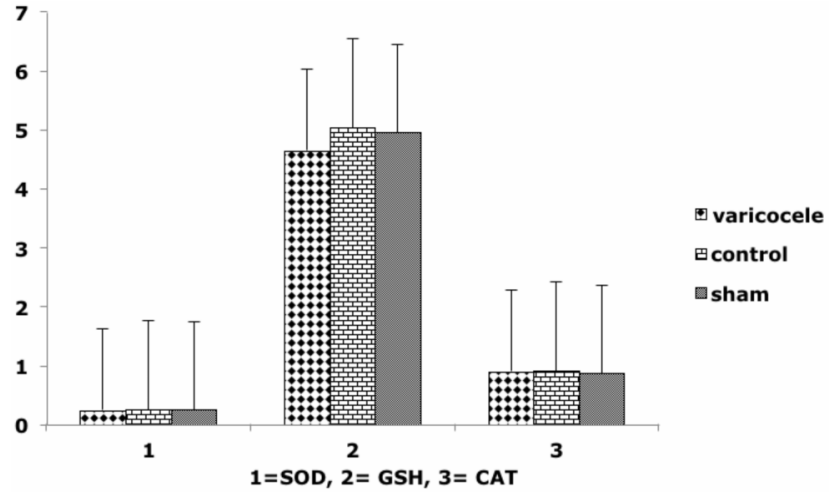

Fig. 4. Shows the graphical representation of biochemical analysis of anti-oxidants enzymatic activities in the three groups on the left ovaries (L).Values are expressed as mean $\pm \mathrm{SD} . *$ means statistically significant difference between the groups $(\mathrm{p} \leq 0.05)$. No statistical difference was found among the groups on the right side. ( $N=5$ in each group).

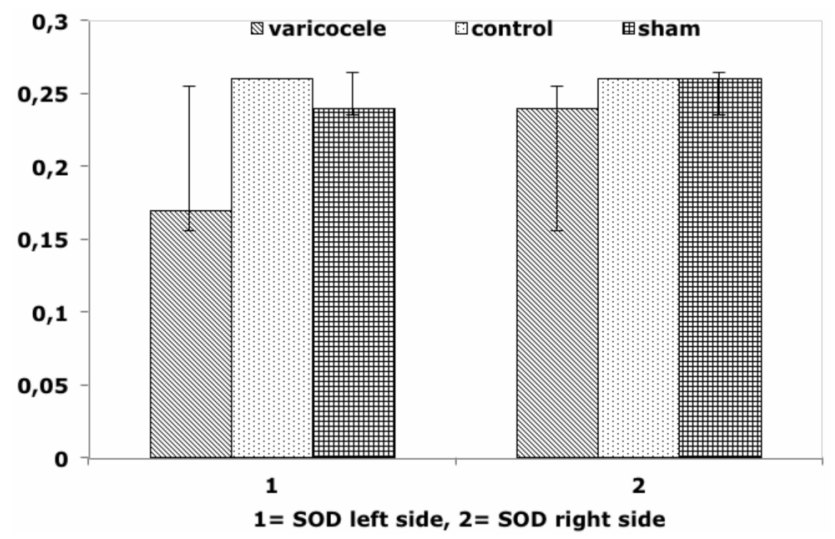

Fig. 5. Shows the graphical representation of biochemical analysis of SOD enzymatic activities in the three groups between the left ovaries (1) and right ovaries(2).Values are expressed as mean \pm $\mathrm{SD}$. * means statistically significant difference between the groups $(p \leq 0.05)$. No statistical difference was found between the right side and left side. ( $\mathrm{N}=5$ in each group).

4.95 \pm 0.09 GSH-Px of Nm tissue in varicocele, control and sham groups, respectively (Fig. 6).

The mean values in left ovaries were $1.2 \pm 0.2$, $4.99 \pm 0.08$ and $4.7 \pm 0.2$ GSH-Px of $\mathrm{nM}$ ovarian tissue in varicocele, control and sham groups respectively (Fig. 6). Statistically, there was no significant difference in the mean values of GSH enzymatic activities of all the groups between the left and right side $(\mathrm{p} \geq 0.05)$.

Catalase enzymatic activities in ovarian tissues. The results of enzymatic activities in right ovaries of all of the three groups were not significantly different from each other $(p>0.05)$. The mean values were $0.89 \pm 0.02,0.91 \pm 0.05$ and 
$0.85 \pm 0.07 \mathrm{CAT}$ of umoles $/ \mathrm{min} / \mathrm{mL}$ tissue in varicocele, control and sham groups, respectively (Fig. 7).

There were significant differences recorded in the mean values in the left ovaries: $0.44 \pm 0.02,0.91 \pm 0.08$, and $0.87 \pm 0.02 \mathrm{CAT}$ of umoles $/ \mathrm{min} / \mathrm{mL}$ ovarian tissue in the three groups respectively (Fig. VII). Significant difference was not recorded among the groups between the left and right side $(\mathrm{p}>0.05)$.

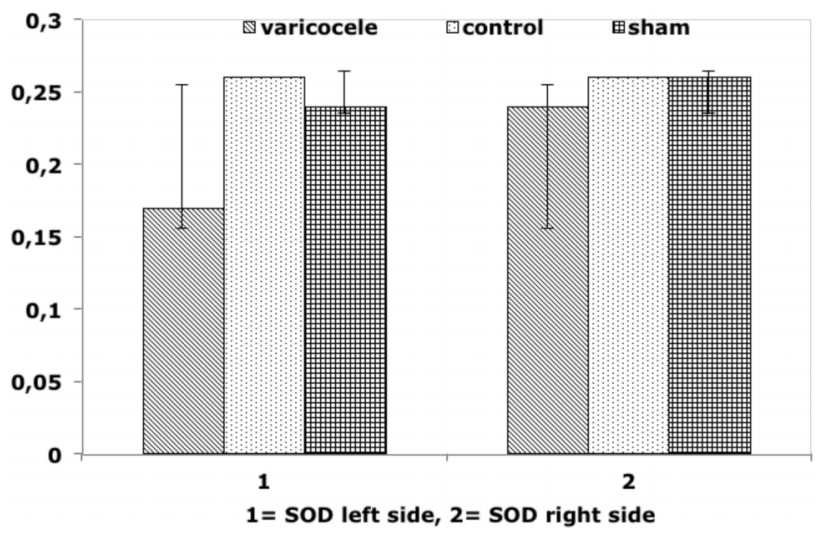

Fig. 6. Shows the graphical representation of biochemical analysis of GSH enzymatic activities in the three groups between the left ovaries (1) and right ovaries(2).Values are expressed as mean \pm $\mathrm{SD}$. * means statistically significant difference between the groups $(\mathrm{p} \leq 0.05)$. No statistical difference was found between the right side and left side. ( $\mathrm{N}=5$ in each group).

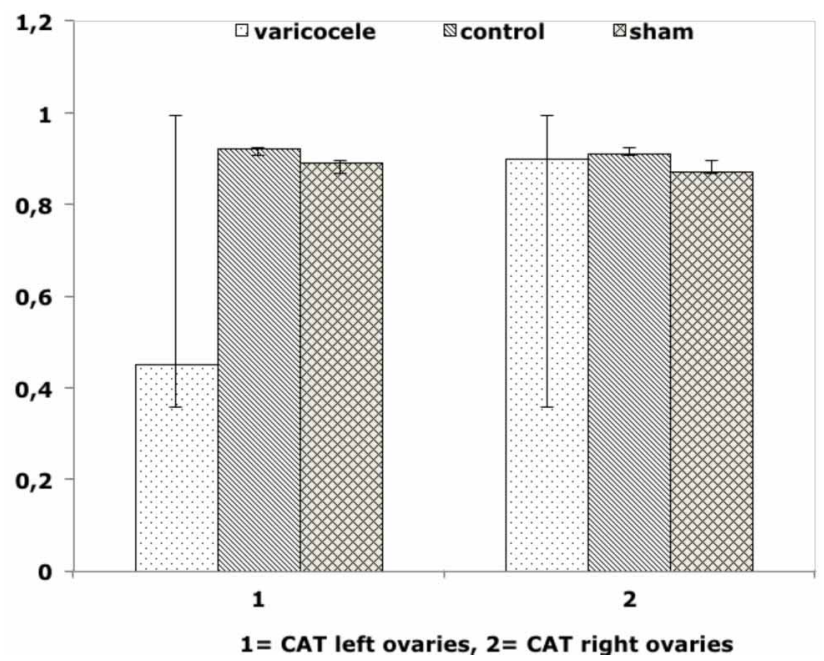

Fig. 7. Shows the graphical representation of biochemical analysis of catalase enzymatic activities in the three groups between the left ovaries (1) and right ovaries (2).Values are expressed as mean $\pm \mathrm{SD}$. * means statistically significant difference between the groups $(p \leq 0.05)$. No statistical difference was found between the right side and left side ( $\mathrm{N}=5$ in each group).

\section{DISCUSSION}

Varicocele is currently one of the major concerns of urology practice. Its relation with infertility is solely based on the clinical observation that indicates a higher incidence in infertile population with a certain improvement in sperm parameters after surgical correction. However, no clear explanation at the molecular level has been shown. Treatment is mainly based on surgical correction of varicocele, although immobilization techniques have been tried for some type of small varicocele. It is also one of the clinical entities that are associated with increased level of ROS. Previous studies reported that oxidative stress parameters (such as ROS and lipid peroxidation) are significantly increased and antioxidant concentrations significantly decreased in varicocele patients and the infertility caused by varicocele is at least partly related to oxygen free radicals (Sharma \& Agarwal, 1996), all these studies are all corroborated by our findings that varicocele induction causes a decrease in the activities of anti-oxidant enzymes.

Hsu et al. (1995), reported that in an animal model of varicocele, superoxide ion was found to be three times higher in experimental varicocele group than control group in animal tissue, which is accordance with our finding that there was an increase in the concentration of superoxide ions as a result of reduction in the activities of superoxide dismutase caused by induced varicocele. Experimental models with surgically created unilateral varicocele in male rats have also confirmed detrimental effects on both testes, our present findings reveals that varicocele worked bilaterally in female rats. In all groups, there were no statistically significant differences between right and left ovaries in terms of activities of the anti-oxidant enzymes (Fig. 3, 4 and 5), though there were differences in the level of dilation and tortuosity of the ovarian vein.

In conclusion, varicocele increased tissue levels of ROS or free radicals on the left induced side in this experimental rat model by reducing the activities of the antioxidants enzymes. Conclusively, our data suggested that decreased activities of these enzymes may lead to infertility in female rats. In addition to surgical interventions to varicose veins treatment, the use of antioxidants may reduce the effects of varicose veins, which requires further investigation.

\section{ACKNOWLEDGEMENTS}

This research was supported by Tehran University of Medical Sciences International campus, Grant $N^{\circ}$ 94-01103-28804. 
KEHINDE, B. A.; ABBASI, N.; ABOLHASSANI, F.; RASTEGAR, T.; DANESHI, E. \& ABBASI, M. Efectos de la inducción experimental unilateral de una vena ovárica varicosa sobre las actividades de las enzimas anti-oxidantes en ovarios de ratas adultas. Int. J. Morphol., 34(4):1436-1441, 2016.

RESUMEN: En este estudio, nuestro objetivo fue examinar los efectos de la inducción experimental unilateral de una vena ovárica varicosa en la actividad de enzimas antioxidantes en un ovario de rata adulta. Un total de 30 ratas albinas Wistar, hembras adultas, se dividieron en tres grupos. Diez ratas en el grupo 1 (grupo varicocele), diez ratas en el grupo 2 (grupo de control) y diez ratas en el grupo 3 (grupo de tratamiento simulado), que se sometió a una operación simulada. Ensayos con anti-oxidantes se evaluaron a través de kits de ensayo específicos. El análisis estadístico se realizó mediante ANOVA de una vía y las pruebas de Tukey fueron utilizadas para comparaciones múltiples Post Hoc, siendo el $\mathrm{P}<0,05$ considerado como estadísticamente significativo. Los efectos de la varicosidad unilateral fue más evidente en el lado izquierdo cuando fue comparada con el lado derecho en todas las actividades del ensayo con anti-oxidante que se redujeron significativamente, el $\mathrm{P} \leq 0,05$ cuando se compara con el lado derecho. Asimismo, en el presente estudio, el efecto de la vena varicosa unilateral fue bilateral ya que no hubo diferencias significativas registradas entre las dos partes. Por último, el resultado de este estudio muestra que el varicocele puede conducir a la infertilidad femenina a través de diversos factores que incluye la reducción en la actividad de las enzimas antioxidantes.

\section{PALABRAS CLAVE: Varicocele; Anti-oxidantes; Unilateral.}

\section{REFERENCES}

Aebi, H. Catalase in vitro. Methods Enzymol., 105:121-6, 1984.

Agarwal, A.; Saleh, R. A. \& Bedaiwy, M. A. Role of reactive oxygen species in the pathophysiology of human reproduction. Fertil. Steril., 79(4):829-43, 2003

Anderson, M. E. \& Luo, J. L. Glutathione therapy: from prodrugs to genes. Semin. Liver Dis., 18(4):415-24, 1998.

Bergmeyer, H. U. Methods of Enzymatic Analysis. New York, Academic Press, 1974. pp.438.

Chan, A. C. Partners in defense, vitamin E and vitamin C. Can. J. Physiol. Pharmacol., 71(9):725-31, 1993.

Choi, H. J.; Kang, S. W.; Yang, C. H.; Rhee, S. G. \& Ryu, S. E. Crystal structure of a novel human peroxidase enzyme at 2.0 A resolution. Nat. Struct. Biol., 5(5):400-6, 1998.

de Matos, D. G. \& Furnus, C. C. The importance of having high glutathione (GSH) level after bovine in vitro maturation on embryo development effect of beta-mercaptoethanol, cysteine and cystine. Theriogenology, 53(3):761-71, 2000.

Durak, I.; Yurtarslani, Z.; Canbolat, O. \& Akyol, O. A methodological approach to superoxide dismutase (SOD) activity assay based on inhibition of nitroblue tetrazolium (NBT) reduction. Clin. Chim. Acta, 214(1):103-4, 1993.

Go, Y. M. \& Jones, D. P. Redox compartmentalization in eukaryotic cells. Biochim. Biophys. Acta, 1780(11):1273-90, 2008.

Hsu, H. S.; Wei, Y. H.; Li, A. F.; Chen, M. T. \& Chang, L. S. Defective mitochondrial oxidative phosphorylation in varicocele-bearing testicles. Urology, 46(4):545-9, 1995.

Jones, D. P. Radical-free biology of oxidative stress. Am. J. Physiol. Cell Physiol., 295(4):C849-68, 2008.

Jozwik, M.; Wolczynski, S.; Jozwik, M. \& Szamatowicz, M. Oxidative stress markers in preovulatory follicular fluid in humans. Mol. Hum. Reprod., 5(5):409-13, 1999.
Laloraya, M.; Pradeep, K. G. \& Laloraya, M. M. Changes in the levels of superoxide anion radical and superoxide dismutase during the estrous cycle of Rattus norvegicus and induction of superoxide dismutase in rat ovary by lutropin. Biochem. Biophys. Res. Commun., 157(1):14653, 1988.

Matés, J. M.; Pérez-Gómez, C. \& Núñez de Castro, I. Antioxidant enzymes and human diseases. Clin. Biochem., 32(8):595-603, 1999.

Paglia, D. E. \& Valentine, W. N. Studies on the quantitative and qualitative characterization of erythrocyte glutathione peroxidase. J. Lab. Clin. Med., 70(1):158-69, 1967.

Pierce, J. D.; Cackler, A. B. \& Arnett, M. G. Why should you care about free radicals? $R N, 67(1): 38-42,2004$.

Roede, J. R. \& Jones, D. P. Reactive species and mitochondrial dysfunction: mechanistic significance of 4-hydroxynonenal. Environ. Mol. Mutagen., 51(5):380-90, 2010.

Sharma, R. K. \& Agarwal, A. Role of reactive oxygen species in male infertility. Urology, 48(6):835-50, 1996.

Tamagno, E.; Aragno, M.; Boccuzzi, G.; Gallo, M.; Parola, S.; Fubini, B.; Poli, G. \& Danni, O. Oxygen free radical scavenger properties of dehydroepiandrosterone. Cell Biochem. Funct., 16(1):57-63, 1998.

Wagner, B.; Buettner, G. R.; Oberley, L. W. \& Burns, C. P. Sensitivity of K562 and HL-60 cells to edelfosine, an ether lipid drug, correlates with production of reactive oxygen species. Cancer Res., 58(13):280916, 1998.

Correspondence to:

Mehdi Abbasi

Anatomy Department

School of Medicine

Tehran University of Medical Sciences

Tehran - IRAN

Email: abbasima@sina.tums.ac.ir

Received: 26-10-2015

Accepted: 11-08-2106 